\title{
STUDENT REACTION TO THE LANGUAGE LABORATORY AT
}

QUEEN'S UNIVERSITY

by Anthony Ibbotson.

\section{Introduction}

In March 1969 it was decided to circulate a questionnaire to gain some impression of the reaction of students taking first-year French courses in the laboratory. 1 The questionnaire was distributed after the students had been exposed to the language laboratory at Queen's University for nearly five months. From the 150 questionnaires returned forty were selected from the group of students in an introduction to honours course - Group A - and forty from those students in a firstyear B.A. General course - Group B. ${ }^{2}$ Both groups had had four to five years of French at High School. It will be noted that in the tables in the appendix not all the students answered every question but this fact does not alter appreciably the results. Percentages, where given, are expressed in terms of the number of replies to a given question.

The regular pre-recorded laboratory lesson was divided into four parts. A short musical introduction, generally a modern French song, enabled the instructor to pass between the boaths and check that each was functioning properly. 3 The repetition exercises which followed were essentially exercises in pronunciation and for part of the year included a separate section on French intonation. These exercises, done by both groups, were printed on sheets and distributed to students at the beginning of each lesson. The explanations on the sheets were also recorded on tape. Occasionally the instructor was asked to enlarge on these explanations during the laboratory lesson.

The transformation exercises in the case of Group A were intended to review grammar covered elsewhere in the course. As far as the content followed the course outline but the vocabulary in these exercises was not directly linked to any text used in the classroom. The exercises chosen for Group B, however, were taken from the laboratory programme of a text used one hour a week in the classroom, and so afforded a much closer link between the language laboratory and the

IFirst-year students have one $\mathbf{5 0}$ minute laboratory period a week in addition to three hours of normal classroom instruction.

${ }^{2}$ As far as possible this was a random selection but those questionnaires with $40 \%$ or more of the sections unanswered, were discarded.

3The language laboratory used by students in first-year French courses is a 36 booth listen-record cartridge laboratory equipped with an instructors' console. 
remainder of the course than was possible to establish with Group A. In some instances the language laboratory exercises were introduced in class beforehand as a way of preparation. These differences do not seem to have affected in any significant way the results indicated in the tables. ${ }^{4}$

The laboratory lesson generally ended with a reading passage. At times the passages were the same for Groups A and B depending on which texts they were taken from. The recorded lesson thus lasted between 20 and 25 minutes leaving 25 minutes for the instructor to go over the lesson and for the students to make corrections. It was obviously during this phase of the lesson that the instructor could listen to and correct student tapes.

\section{Analysis of the Questionnaire}

Questions 1.4: How much do you think the language laboratory has helped to improve your (1) accent, (2) intonation, (3) grammar, and (4) fluency?

Over $50 \%$ of the students felt that there had been a marked improvement in their accent - (Question 1, columns 1 and 2) - whereas less than $20 \%$ noted a corresponding improvement in their fluency: in fact nearly $40 \%$ indicated that their fluency had not improved at all. $76 \%$ felt that the language laboratory had been of little or no use in helping them improve their grammar - (Question 3, columns 3 and 4 ), and $61 \%$ held the same opinion for the intonation exercises. As far as students are concerned the laboratory would appear to be of greatest use in helping them to improve their accent.s

Question 5: Did you find the repetition exercises (i) very useful, (ii) useful or (iii) of little use?

Question 6: Were the recorded explanations (i) very useful, (ii) useful or (iii) of little use?

The majority of both groups clearly found the repetition exercises and the recorded explanations useful - (Question 5 and 6, columns 1 and 2). These figures support the conclusion reached from the figures in the appendix for Questions 14. One student described the repetition as being the most important work done in the laboratory.

Question 7: Did you find the transformation exercises (i) very useful, (ii) useful or (iii) of little use?

Question 8: Do you think that the instructor should explain briefly the points of grammar in these exercises? (i) yes, (ii) no or (iii) indifferent?

4 See questions 7 and 8 in the appendix.

SThe distinction between accent and intonation is purely arbitrary but as some of the exercises were primarily concerned with intonation patterns it was decided to include these separately on the questionnaire. 
The majority of the students found the transformation exercises useful with only $8 \%$ feeling they were of little use. As the transformation exercises were primarily intended to review the student's knowledge of French grammar it is interesting to note the apparent inconsistency between the usefulness of this type of exercise as expressed by the majority of the students and the small percentage who felt that the language laboratory had markedly improved their grammar. This raises the question of the difficulties experienced by students and laboratory directors in relating work and progress in the laboratory to such exercises as translations into French and essay writing.

As far as Group $A$ is concerned no detailed explanation of the points of grammar was given in the language laboratory. The exercises for Group B were taken from a course text book and related directly to work covered elsewhere. But in spite of this difference both groups clearly indicated that they would prefer some explanation of the grammar at the beginning of the laboratory lesson. This would suggest that the policy adopted in 1969 of refraining from detailed grammatical explanations was not acceptable to most students. This year all the instructors have been required to explain briefly the points of grammar in the transformation exercises. So far no students have objected to this.

Question 9: Would you prefer the explanations to be in (i) French, (ii) English, (iii) immaterial?

Whilst $23 \%$ of the students indicated that they would prefer the explanations for the transformation exercises to be in English and a similar percentage indicated that they had no fixed preference, $54 \%$ preferred the explanations to be in French. Some students firmly stated that all English should be banned from the laboratory. This desire for all instruction to be in French reflected in other parts of the courses.

Questions 10-12: Would you like the sheets for the repetition, intona. tion and transformation exercises to be distributed (i) at the beginning of the lesson, (ii) when you have recorded the lesson for the 1st time, (iii) at the end of the lesson or (iv) indifferent?

The strain of having to sit through a fifty-minute laboratory period without a written text in front of them was too much for most students. Students in Group A and B favoured having the written text in front of them for the repetition and intonation exercises. On the other hand, for the transformation exercises the majority in Group A favoured having the text distributed after they had recorded the lesson 
once. Students are fully aware that they have no written text for the annual laboratory examination held in April and this may have prompted several students to prefer recording the lesson once without any visual support.

The total figures for the repetition and transformation exercises would suggest that the students are divided as to whether they prefer doing this type of exercise once without any visual support. For the intonation exercises a clear preference is indicated for the written texts to be distributed at the beginning of the lesson.

Question 13: Did you find the reading passage (i) useful, (ii) not useful?

This exercise was clearly well-liked by most students. The reading extracts were taken from texts studied elsewhere and were either prose passages or plays. Students in Group B were often required to read the role of one of the characters and were thus able to play opposite a professional French actor. Generally this type of reading passage was well received although some students indicated in their answers a distinct preference for the prose passage.

Question 14: Did you find your language laboratory instructor (i) good, (ii) all right, (iii) useless?

The six laboratory instructors were, with two exceptions, native French speakers and only one of the six holds any professional language-laboratory qualifications. All received good or satisfactory comments from their students and it was obvious that the students welcomed having a native French speaker as an instructor.

Question 15: Of the work done in the language laboratory what did. you find the most interesting (i) repetition exercises, (ii) intonation exercises, (iii) transformation exercises, (iv). the song at the beginning of the lesson or (v) the reading passage?

Whilst the reading exercises proved to be popular it was somewhat surprising to learn that the repetition exercises were equally well received by the students and, furthermore, that the French songs at the beginning of the lesson were mentioned by $30 \%$ of the students.

Question 16: Of the work done in the language laboratory what did you find the least interesting (i) repetition exercises, (ii) intonation exercises, (iii) transformation exercises or (iv) the reading passage?

The figures for Question 15 in the appendix suggest that transformation exercises were not very popular with students. This is indi- 


\section{Student Reaction}

cated also by the figures for Question 16 which show this type of exercise to be the least interesting work done in the laboratory. Repetition and intonation exercises ranked second and third in unpopularity. Whilst one student considered everything to be useful in the laboratory most students preferred to single out one or two aspects of laboratory work as being most interesting. This explains why the total in Question 15 exceeds the number of questionnaires analyzed. Students, however, were less ready to mention the least interesting exercise in the laboratory. One or two students despite their lack of enthusiasm for transformation exercises admitted that they were either useful or necessary. No student objected to the French song at the beginning of the lesson although at times they questioned the selection.

Question 17: If you did not attend language laboratory lessons this year on a regular basis was this because of (i) the time eg. Monday 8:30 a.m., (ii) laziness, (iii) failure to understand the purpose of language laboratory, (iv) boredom, $(v)$ instructor or (vi) other reasons?

In September 1969 when language laboratory classes began attendance corresponded closely to the number of students enrolled in each course. During the year, however, attendance showed noticeable decrease and improved only a month before the laboratory examinations in April. Boredom and laziness appear largely responsible for this decrease in attendance. $25 \%$ of the students admitted they did not attend regularly and this in itself should be cause for reflection. Attendance in the laboratory is not compulsory and there are no written assignments to hand in although the language laboratory exam in both Groups A and B counts for $20 \%$ of the final mark. The repetitive element associated with laboratory work and the difficulty in noticing immediate or rapid progress may help to explain the boredom experienced by several students. Sustained motivation and interest in language laboratory work are difficult to achieve and place considerable demands on the resourcefulness of the language laboratory director.

Question 18: How often a week and for how long did you use the practice laboratory? (i) never, (ii) seldom, (iii) 0-30 min. once a week, (iv) 0-30 min. twice a week, (v) 0-30 min. more than twice a week, (vi) 30-1 hr. once a week, (vii) 30-1 hr. twice a week, (viii) 30-1 hrs. more than twice a week, (ix) $1 \cdot 11 / 2 \mathrm{hr}$. once a week?

Question 19: Is the practice laboratory useful? (i) yes, (ii) no? 
Question 20: If you seldom used the practice laboratory was this on account of (i) laziness, (ii) lack of interest, (iii) failure to see the purpose of the practice laboratory or (iv) other reasons?

Those students who used the practice laboratory tended to do so once a week for up to 30 minutes. 6 Nearly as many students, however, spent longer reviewing their lessons. but $53 \%$ used this laboratory seldom or never at all. Attendance in the practice laboratory is purely voluntary, there is no instructor on duty and there is no check on how often a student actually uses it. Its advantages are nevertheless stressed throughout the year. It is obvious that a fairly large group of students have chosen not to go to the practice laboratory either through laziness or lack of interest. Many students felt that if they could correct their recording in the laboratory period supervised by the instructor this was sufficient. Some students stated that on account of other courses, they could not afford the time to use the practice laboratory regularly even though they recognized its purpose. The student most likely to use this laboratory is already highly motivated. Whilst $53 \%$ seldom used the practice laboratory or never at all, $73 \%$ felt that this laboratory was useful. The practice laboratory is put to good use by students for revision purposes just before examinations in April.

At the end of the questionnaire the students were asked for other comments concerning the laboratory. One or two students aptly remarked that merely doing the exercises correctly did not necessarily make them more fluent in French. This raises the problem of relating exercises done in the laboratory to the normal speaking situation. Several students felt that the language laboratory did not provide them with such a situation and there were fifteen requests for conversation lessons. As a result of this questionnaire it was possible to arrange a limited number of voluntary conversation lessons which have proved most popular. Other points raised by students were concerned with minor technical problems encountered in the practice laboratory last year.

The purpose of the questionnaire was to obtain some idea of student reaction to work done in the language laboratory at Queen's University. It has been necessary to take student opinion at face value even though one may be tempted to doubt its validity at times. In

6The practice laboratory consists of 18 listen-record cartridge recorders as well as two open-reel tape recorders. The latter enable all students in the Department of French to listen to the extensive selection of recorded plays and songs in the tape library. 


\section{Student Reaction}

this respect one feels that the transformation exercises, by providing a survey of grammar, have been more useful than most students would admit. According to the students, the laboratory has been most successful in improving their accent and least progress has been in fluency and grammar. The instructor has been considered necessary in the laboratory and students have obviously valued contact with a native French speaker in an otherwise impersonal teaching situation as emphasized by their requests for conversation lessons and the support that these have subsequently received. Whilst some students have shown a keen interest in the language laboratory because they already have a keen interest in learning a foreign language, $25 \%$ of the students readily admitted that they did not attend the language laboratory classes regularly. The problem now is to find ways of improving the lessons and making them more interesting and varied in the hopes that this will attract students to the laboratory and not turn them away. 


\section{APPENDIX}

Student Reaction

How much do you think the language laboratory has helped to improve your ....?

1.

ACCENT

\begin{tabular}{l|c|c|c|c|c}
\hline Group & $\begin{array}{c}\text { a lot } \\
(1)\end{array}$ & $\begin{array}{c}\text { more than a little } \\
\text { (2) }\end{array}$ & $\begin{array}{c}\text { a litcle } \\
\text { (3) }\end{array}$ & $\begin{array}{c}\text { not at all } \\
\text { (4) }\end{array}$ & Total \\
\hline A & 11 & 12 & 10 & 6 & 39 \\
\hline B & 7 & 15 & 16 & 2 & 40 \\
\hline Total & 18 & 27 & 26 & 8 & 79 \\
\hline
\end{tabular}

2.

\section{INTONATION}

\begin{tabular}{l|c|c|c|c|c}
\hline Group & $\begin{array}{c}\text { a lot } \\
\text { (1) }\end{array}$ & $\begin{array}{c}\text { more than 2 little } \\
\text { (2) }\end{array}$ & $\begin{array}{c}\text { (little } \\
\text { (3) }\end{array}$ & $\begin{array}{c}\text { aot at all } \\
\text { (4) }\end{array}$ & Total \\
\hline A & 8 & 7 & 14 & 9 & 38 \\
\hline B & 8 & 7 & 18 & 6 & 39 \\
\hline Total & 16 & 14 & 32 & 15 & 77 \\
\hline
\end{tabular}

3.

GRAMMaR

\begin{tabular}{l|c|c|c|c|c}
\hline Group & $\begin{array}{c}\text { 2 lot } \\
\text { (1) }\end{array}$ & $\begin{array}{c}\text { more than a lizcle } \\
\text { (2) }\end{array}$ & $\begin{array}{c}\text { 2 little } \\
\text { (3) }\end{array}$ & $\begin{array}{c}\text { not at all } \\
\text { (4) }\end{array}$ & Total \\
\hline A & 3 & 10 & 17 & 8 & 38 \\
\hline B & 1 & 4 & 22 & 13 & 40 \\
\hline Total & 4 & 14 & 39 & 21 & 78 \\
\hline
\end{tabular}

4.

FLUENCI

\begin{tabular}{l|c|c|c|c|c}
\hline Group & $\begin{array}{c}\text { 2 lot } \\
\text { (1) }\end{array}$ & $\begin{array}{c}\text { more than 2 little } \\
\text { (2) }\end{array}$ & $\begin{array}{c}\text { a little } \\
\text { (3) }\end{array}$ & $\begin{array}{c}\text { not at all } \\
\text { (4) }\end{array}$ & Total \\
\hline A & 2 & 2 & 19 & 16 & 39 \\
\hline B & 3 & 5 & 16 & 14 & 38 \\
\hline Total & 5 & 7 & 35 & 30 & 77 \\
\hline
\end{tabular}




\section{Student Reaction}

5.

Did you find the repetition exercises ... . ?

\begin{tabular}{l|c|c|c|c}
\hline Group & $\begin{array}{c}\text { very useful } \\
\text { (1) }\end{array}$ & $\begin{array}{c}\text { useful } \\
\text { (2) }\end{array}$ & $\begin{array}{c}\text { of lixtle use } \\
\text { (3) }\end{array}$ & Total \\
\hline A & 9 & 24 & 7 & 40 \\
\hline B & 16 & 15 & 9 & 40 \\
\hline Total & 25 & 39 & 16 & 80 \\
\hline
\end{tabular}

6.

Were the recorded explanations ... ?

\begin{tabular}{l|c|c|c|c}
\hline Group & $\begin{array}{c}\text { very useful } \\
\text { (1) }\end{array}$ & $\begin{array}{c}\text { useful } \\
\text { (2) }\end{array}$ & $\begin{array}{c}\text { of little use } \\
\text { (3) }\end{array}$ & Total \\
\hline$A$ & 13 & 13 & 1.1 & 37 \\
\hline B & 10 & 21 & 7 & 38 \\
\hline Total & 23 & 34 & 18 & 75 \\
\hline
\end{tabular}

7.

Did you find the transformation exercises ... . ?

\begin{tabular}{l|c|c|c|c}
\hline Group & $\begin{array}{c}\text { very useful } \\
\text { (1) }\end{array}$ & $\begin{array}{c}\text { uscful } \\
\text { (2) }\end{array}$ & $\begin{array}{c}\text { of lìtle use } \\
\text { (3) }\end{array}$ & Total \\
\hline A & 19 & 17 & 3 & 39 \\
\hline B & 16 & 20 & 4 & 40 \\
\hline Total & 35 & 37 & 7 & 79 \\
\hline
\end{tabular}

8.

Do you think that the instructor should explain briefly the points of grammar in these exercises?

\begin{tabular}{l|c|c|c|c}
\hline Group & $\begin{array}{l}\text { Yes } \\
(1)\end{array}$ & $\begin{array}{c}\text { No } \\
(2)\end{array}$ & $\begin{array}{c}\text { indifferent } \\
(3)\end{array}$ & Total \\
\hline A & 23 & 9 & 7 & 39 \\
\hline B & 27 & 11 & 2 & 40 \\
\hline Total & 50 & 20 & 9 & 79 \\
\hline
\end{tabular}


9.

Would you prefer the explanations to be in ... ?

\begin{tabular}{l|c|c|c|c}
\hline Group & French & English & Immaterial & Total \\
\hline A & 25 & 7 & 6 & 38 \\
\hline B & 17 & 11 & 12 & 40 \\
\hline Total & 42 & 18 & 18 & 78 \\
\hline
\end{tabular}

10.

Would you like the sheets for the repetition exercises to be distributed ....?

\begin{tabular}{l|c|c|c|c|c}
\hline Group & $\begin{array}{c}\text { 2t the beginning } \\
\text { of the lesson } \\
\text { (1) }\end{array}$ & $\begin{array}{c}\text { when you have re- } \\
\text { corded the lesson for } \\
\text { che 1st time. (2) }\end{array}$ & $\begin{array}{c}\text { at the end of } \\
\text { the lesson } \\
\text { (3) }\end{array}$ & $\begin{array}{c}\text { indifferent } \\
\text { (4) }\end{array}$ & Total \\
\hline A & 18 & 15 & 2 & 2 & 37 \\
\hline B & 20 & 19 & & 1 & 40 \\
\hline Total & 38 & 34 & 2 & 3 & 77 \\
\hline
\end{tabular}

11.

Would you like the sheets for the intonation exercises to be distributed ...?

\begin{tabular}{l|c|c|c|c|c}
\hline Group & $\begin{array}{c}\text { at the beginning } \\
\text { of the lesson } \\
\text { (1) }\end{array}$ & $\begin{array}{c}\text { when you have re- } \\
\text { corded the lesson for } \\
\text { the 1st time. (2) }\end{array}$ & $\begin{array}{c}\text { at the end of } \\
\text { the lesson } \\
\text { (3) }\end{array}$ & $\begin{array}{c}\text { indifferent } \\
\text { (4) }\end{array}$ & Total \\
\hline A & 19 & 15 & 1 & 4 & 39 \\
\hline E & 25 & 13 & & 2 & 40 \\
\hline Total & 44 & 28 & 1 & 6 & 79 \\
\hline
\end{tabular}

12.

Would you like the sheets for the transformation exercises to be distributed ... . ?

\begin{tabular}{l|c|c|c|c|c}
\hline Group & $\begin{array}{c}\text { at the beginning } \\
\text { of the lesson } \\
\text { (1) }\end{array}$ & $\begin{array}{c}\text { when you have re- } \\
\text { corded the lesson for } \\
\text { the 1st time. (2) }\end{array}$ & $\begin{array}{c}\text { at the end of } \\
\text { the lesson } \\
\text { (3) }\end{array}$ & $\begin{array}{c}\text { indifferent } \\
\text { (4) }\end{array}$ & Total \\
\hline A & 14 & 21 & 2 & 2 & 39 \\
\hline B & 22 & 14 & 1 & 3 & 40 \\
\hline Total & 36 & 35 & 3 & 5 & 79 \\
\hline
\end{tabular}


Student Reaction

13.

Did you find the reading passages ... ?

\begin{tabular}{l|c|c|c}
\hline Group & useful & not useful & Total \\
\hline A & 33 & 4 & 37 \\
\hline B & 28 & 10 & 38 \\
\hline Total & 61 & 14 & 75 \\
\hline
\end{tabular}

14.

Did you find your language laboratory instructor . . . ?

\begin{tabular}{l|c|c|c|c}
\hline Group & 800d & all right & useless & Total \\
\hline A & 13 & 11 & 1 & 25 \\
\hline B & 26 & 6 & 1 & 33 \\
\hline Total & 39 & 17 & 2 & 58 \\
\hline
\end{tabular}

15.

Of the work done in the language laboratory what did you find the most interesting?

\begin{tabular}{l|c|c|c|c}
\hline Group & $\begin{array}{c}\text { sepetition } \\
\text { exercises }\end{array}$ & $\begin{array}{c}\text { intonation } \\
\text { exercises }\end{array}$ & $\begin{array}{c}\text { transformation } \\
\text { excreises }\end{array}$ & Total \\
\hline A & 6 & 3 & 8 & 17 \\
\hline B & 21 & 8 & 4 & 33 \\
\hline Total & 27 & 11 & 12 & 50 \\
\hline
\end{tabular}

\begin{tabular}{l|c|c|c}
\hline Group & $\begin{array}{c}\text { the song at the beginning } \\
\text { of the lesson }\end{array}$ & reading passage & Total \\
\hline A & 11 & 17 & 28 \\
\hline B & 13 & 9 & 22 \\
\hline Total & 24 & 26 & 50 \\
\hline & & & 100 \\
\hline
\end{tabular}


16.

Of the work done in the language laboratory what did you find the least interesting?

\begin{tabular}{l|c|c|c}
\hline Group & $\begin{array}{c}\text { repetzition } \\
\text { exercises }\end{array}$ & $\begin{array}{c}\text { intonation } \\
\text { exercises }\end{array}$ & Total \\
\hline A & 8 & 7 & 15 \\
\hline B & 5 & 4 & 9 \\
\hline Total & 13 & 11 & 24 \\
\hline
\end{tabular}

\begin{tabular}{l|c|c|c}
\hline Group & $\begin{array}{c}\text { transformation } \\
\text { exercises }\end{array}$ & $\begin{array}{c}\text { reading } \\
\text { passage }\end{array}$ & Total \\
\hline A & 13 & 1 & 14 \\
\hline B & 13 & 6 & 19 \\
\hline Total & 26 & 7 & 33 \\
\hline & & & 57 \\
\hline
\end{tabular}

$1 \%$.

If you did not attend language laboratory lessons this year on a regular basis was this because of ...

\begin{tabular}{l|c|c|c|c}
\hline Group & $\begin{array}{c}\text { the time eg. } \\
\text { Monday 8:30 2.m. }\end{array}$ & laziness & $\begin{array}{c}\text { failure to understand } \\
\text { the purpose of } \\
\text { language laboratory }\end{array}$ & Total \\
\hline A & 1 & 3 & 1 & 5 \\
\hline B & 1 & 2 & 2 & 5 \\
\hline Total & 2 & 5 & 3 & 10 \\
\hline
\end{tabular}

\begin{tabular}{l|c|c|c|c}
\hline Group & boredom & instructor & $\begin{array}{c}\text { other } \\
\text { reasons }\end{array}$ & Total \\
\hline A & 5 & & & 5 \\
\hline B & 3 & & 2 & 5 \\
\hline Total & 8 & & 2 & 10 \\
\hline
\end{tabular}




\section{Student Reaction}

18.

How often a week and for how long did you use the practice laboratory?

\begin{tabular}{l|c|c|c|c|c|c}
\hline Group & never & seldom & $\begin{array}{c}0.30 \text { min. } \\
\text { once 2 } \\
\text { week }\end{array}$ & $\begin{array}{c}0.30 \text { min. } \\
\text { twice 2 } \\
\text { weck }\end{array}$ & $\begin{array}{c}0-30 \text { min. } \\
\text { wore than } \\
\text { twice a } \\
\text { week }\end{array}$ & Total \\
\hline A & 6 & 7 & 12 & 2 & 2 & 29 \\
\hline B & 12 & 14 & 8 & & & 34 \\
\hline Total & 18 & 21 & 20 & 2 & 2 & 63 \\
\hline
\end{tabular}

\begin{tabular}{l|c|c|c|c|c}
\hline Group & $\begin{array}{c}30-1 \text { hr. } \\
\text { once a } \\
\text { week }\end{array}$ & $\begin{array}{c}30-1 \text { hr. } \\
\text { twice a } \\
\text { week }\end{array}$ & $\begin{array}{c}30-1 \text { hr. } \\
\text { more than } \\
\text { twice 2 } \\
\text { week }\end{array}$ & $\begin{array}{c}1-1 \frac{1}{2} \text { hr. } \\
\text { once 2 } \\
\text { week }\end{array}$ & Total \\
\hline A & 3 & 1 & 1 & 2 & 7 \\
\hline B & 2 & 2 & & & 4 \\
\hline Total & 5 & 3 & 1 & 2 & 11 \\
\hline
\end{tabular}

19.

Is the practice laboratory useful?

\begin{tabular}{l|c|c|c}
\hline Group & yes & no & Tocal \\
\hline A & 30 & 6 & 36 \\
\hline B & 23 & 13 & 36 \\
\hline Total & 53 & 19 & 72 \\
\hline
\end{tabular}

20.

If you seldom used the practice laboratory was this on account of ...

\begin{tabular}{l|c|c|c|c|c}
\hline Group & laziness & $\begin{array}{c}\text { lack of } \\
\text { interest }\end{array}$ & $\begin{array}{c}\text { failure to see the } \\
\text { purpose of the } \\
\text { practice laboratory }\end{array}$ & other reasons & Total \\
\hline A & 12 & 5 & 2 & 9 & 28 \\
\hline B & 12 & 11 & 5 & 11 & 39 \\
\hline Total & 24 & 16 & 7 & 20 & 67 \\
\hline
\end{tabular}

